\title{
Eddy Vertical Structure in Southern Java Indian Ocean: Identification using Automated Eddies Detection
}

\author{
Armyanda Tussadiah ${ }^{1,3}$, Mega L. Syamsuddin², Widodo S. Pranowo ${ }^{3}$, Noir P. Purba ${ }^{2}$, Indah Riyantini ${ }^{2}$ \\ ${ }^{1}$ KOMITMEN Research Group, Dekanat Building, Padjadjaran University Jatinangor Km. 21 UBR 40600, West Java, Indonesia \\ ${ }^{2}$ Departement of Marine Science, Padjadjaran University, Dekanat Building, FPIK-UNPAD Jatinangor Km. 21 UBR 40600, West Java, \\ Indonesia \\ ${ }^{3}$ Marine and Coastal Data Laboratory, R \& D Center for Marine \& Coastal Resources, Agency for Marine \& Fisheries R \& D, Ministry of \\ Marine Affairs \& Fisheries Republic of Indonesia \\ Pasir Putih II, East Ancol, Jakarta UBR 14430, Indonesia
}

\begin{abstract}
The eddy characteristic in Southern Java Indian Ocean has been investigated and discussed, but spesifically deals about the vertical structure of eddy is still not much. This research was conducted to determine the eddy vertical characteristic and to find out the biggest value of kinematic energy between the cyclonic and anticyclonic eddy. The data set was from NEMO model with parameter are current and temperature from 2014. By using an automated eddy detection the veertical eddies characteristic was set developed, it includes the statistical data of each eddy location, radius, kinematic energy, temperature, and SSH at four vertical levels. The results indicated that cyclonic eddy is mostly formed in Southern Java Indian Ocean in 2014. The temperature in eddy center mostly started changing at a depth of 109 m, which is at the cyclonic eddy has a lower value and at anticyclonic has a higher value.
\end{abstract}

Keywords: Eddies, vertical structure, cyclonic eddy, anticyclonic eddy, kinematic energy.

\section{Introduction}

Indian Ocean waters has a unique and complex properties dynamics because the water system were affected by monsoon and trade wind system, unlike the Pacific Ocean and the Atlantic are only influenced by the trade wind system. In these waters there are several oceanography phenomena which have an important influence not only for oceanography but also for the atmosphere, such as Indian Ocean Dipole (IOD), upwelling, South Equatorial Current (SEC), South Java Current (SJC) and eddy [1].

An eddy is a loop of current that is cut off from the main current, or a small, spinning current. Ocean eddy can move at speeds of about 0.5 knots and may occasionally persist for many month [2]. Spatial distribution of eddy varies with the size. All eddy are categorized into two groups according to their size: a submesoscale eddy is about $10-100 \mathrm{~km}$, and a mesoscale eddy can reach more then 50-200 km [3]. There are warm-core eddy and cold-core eddy. In southern hemisphere cold-core eddy rotate clockwise or known as a cyclonic eddy, while the warm-core eddy rotate counterclockwise or known as anticyclonic eddy. The cyclonic eddy can drive upwelling in their interior and increasing primary production [4].

Eddy are important because they have so much kinetic energy, and because they can transport momentum and trace water properties. They have deep, ,roots ${ }^{\text {ee }}$ that often reach 5 $\mathrm{km}$ or more downward, carrying energy and momentum to the seafloor. They are responsible for the irreversible mixing of waters with different properties. They may owe their existence to several sources other than meandering of strong currents: for example, direct generation by winds or cooling at the sea surface; flow over a rough seafloor or past islands and coastal promentories; or generation by mixing or waves of smaller scale [5].

Most of the former eddy studies in Southern Java Indian Ocean are focused on the surface and little is known about the vertical structures of eddies in the region. The first research about eddy in Southern Java was by Creswell and Golding in 1977 using drifter trajectories [2]. In this paper, we used a automated eddy detection developed by Nencioli et al. (2010) to analyze and identify the vertical eddy structures and characteristics.

\section{Methodology}

The study region extend from Southern Java Indian Ocean $\left(0^{\circ}-20^{\circ} \mathrm{S}\right.$ and $\left.90^{\circ}-120^{\circ} \mathrm{E}\right)$. The data set was from NEMO Model from INDESO website (www.indeso.com). This model is forced at the surface using 3-hourly ECWMF atmospheric analysis and forecast fields and at the lateral open boundaries using Mercator Océan global operational analysis and forecast fields.

\subsection{Ocean Model Data}

The ocean model used by INDESO is a "regional" version of the OPA/NEMO global ocean circulation model. This regional model was developed by France (MERCATOR OCEAN) and is now used to simulate very accurately (at high resolution) ocean circulation around the world. The parameter that used to identify the eddy characteristic are vertical current (U and V component) and temperature with 


\section{International Journal of Science and Research (IJSR) \\ ISSN (Online): 2319-7064}

Index Copernicus Value (2013): 6.14 | Impact Factor (2014): 5.611

the resolution $0.08^{\circ}$ and daily composite data from 2014. It is distributions at four vertical level $(5 \mathrm{~m}, 109 \mathrm{~m}, 155 \mathrm{~m}$, and $222 \mathrm{~m})$.

\subsection{Eddy Kinetic Energy}

To get the value of eddy kinetic energy, it is computed from velocity components using the classical relation:

$$
\mathrm{EKE}=1 / 2\left(\mathrm{U}^{2}+\mathrm{V}^{2}\right)
$$

Where:

EKE = Eddy kinetic energy

$\mathrm{U} \quad=\mathrm{u}$ current vector $/ \mathrm{zonal}(\mathrm{cm} / \mathrm{s})$

$\mathrm{V}=\mathrm{v}$ current vector $/$ meridional $(\mathrm{cm} / \mathrm{s})$

\subsection{Automated Eddy Detection Scheme}

In detection the existence of eddy was using the automated eddy detection algorithm which developed by Nencioli et al. (2010). The method can be applied to any velocity field. It has been applied to eddy detection in Hawaiian Islands wake by Dong et al. (2009). The method is based on some of the features that characterize the velocity field associated with mesoscale eddies, such as minimum velocities in the proximity of the eddy center, and tangential velocities that increase approximately linearly with distance from the center before reaching a maximum value and then decaying [7]. Four constraints were derived in conformance with the eddy velocity field definition and characteristics described above. Eddy centers are determined at the points where all of the constraints are satisfied. The four constraints follow: [8]

(i) along an east-west (EW) section, meridional velocity (v) has to reverse in sign across the eddy center and its magnitude has to increase away from it,

(ii) along a north-south (NS) section, zonal celocity (u) has to reverse in sign across the eddy center and its magnitude has to increase away from it: the sense of rotation has to be the same as for $\mathrm{v}$,

(iii) velocity magnitude has a local minimum at the eddy center, and

(iv) around the eddy center, the directions of the velocity vectors have to change with a constant sense of rotation and the directions of two neighboring velocity vectors have to lay within the same or two adjacent quadrants.

\section{Results and Discussion}

\subsection{Eddy Frequency}

With the application of automated eddy detection at four vertical levels, the occurence of eddy shows significant seasonal variation. The maximum total of cyclonic eddy occur in January - March and July - September, while the anticyclonic eddy in April - June and July - September. The formation of cyclonic eddy dominated in the Southern Java Indian Ocean during 2014, with total of cyclonic eddy are 1096 and anticyclonic are 1033. Mostly the formation of eddy increasing at $109 \mathrm{~m}-222 \mathrm{~m}$. The increasing of eddy at $109 \mathrm{~m}$ - $222 \mathrm{~m}$ maybe come from the differences of generating eddy vertically like wind stress, kelvin and rosby waves, topography, and baroclinic instability [9].
Figure 1 shows the formation eddy at four vertical levels during September 2014, which red (black) circle depict cyclonic (anticyclonic) eddy. A 186 total of eddy were identified during this month, with 98 were cyclonic eddy and 88 were anticyclonic eddy. Increasing of cyclonic eddy in September 2014 maybe caused by the instability of Indonesian Thorughflow (ITF) that reach maximum flow during Southeast Monsoon. Because of the high intensity of ITF, the formation of eddy driven into South Indian Ocean $\left(14^{\circ}-20^{\circ} \mathrm{S}\right)$. At the surface eddy has a variety diameter, along $16^{\circ}-20^{\circ} \mathrm{S}$ dominated with the submesoscale eddy (50 - $100 \mathrm{~km})$. The appearance of submesoscale eddy maybe come from drifter aggregation, maintained by converging ekman currents [10], [11]. At 109 m - 222 m eddy formation spread well in Southern Java Indian Ocean and mostly dominated by mesoscale eddy ( $80-200 \mathrm{~km})$ and the larger eddy mostly formed in SEC pathways. There are several eddy that can formed well from surface to $222 \mathrm{~m}$. Example an anticyclonic eddy with coordinate at $113.7^{\circ} \mathrm{E}$ and $14.4^{\circ} \mathrm{S}$ can reach to $222 \mathrm{~m}$, this eddy have a variety diameter vertically. At surface the diameter is $241 \mathrm{~km}$, while in $222 \mathrm{~m}$ is $291 \mathrm{~km}$. This eddy also called as cone-shaped (an eddy has the largest size at the bottom).

During November and December 2014 the cyclonic and anticyclonic eddy fomation decreasing vertically. At the surface has a lower of total cyclonic and anticyclonic eddy. Decreasing of the eddy formation during November December maybe affected by the lack of ITF flow. Furthermore during March 2014 the total cyclonic eddy has decreasing while the total anticyclonic eddy has increasing. Decreasing of cyclonic eddy maybe affected by the lack of SJC flow from Southwest Sumatra, while increasing of anticyclonic eddy maybe affected by other phenomenon occur in Indian Ocean such as kelvin wave. Kelvin waves leading to a shallower thermocline with lower sea surface height in the east Indian Ocean [12].

\subsection{Temperature at Eddy}

The temperature characteristic at eddy center shows at the cyclonic eddy has a lower value than anticylonic and its surrounding water. In the surface was covered with homogeneous warm water $\left(28-30^{\circ} \mathrm{C}\right)$. At surface $(5 \mathrm{~m})$ the existence of cold-core eddy (cyclonic eddy) and warm-core eddy (anticyclonic eddy) was invisible. It maybe caused by the time lag about 10 days between the increase of eddy from the bottom layer to the upper layer [13]. The temperature in the eddy center gradually decreased at $109 \mathrm{~m}$ and start fading at $222 \mathrm{~m}$, so that in cyclonic eddy shows the existence of upwelling while anticyclonic eddy shows the existence of downwelling. Mean temperature at cyclonic eddy at $109 \mathrm{~m}$ was about $19.41^{\circ} \mathrm{C}$ while at anticyclonic eddy was about $20.88^{\circ} \mathrm{C}$, and at $222 \mathrm{~m}$ the mean temperature has not significant difference which at cyclonic eddy was about $14.98^{\circ} \mathrm{C}$ and at anticyclonic eddy was about $15.88^{\circ} \mathrm{C}$.

In September 2014 was a strongest intesity of temperature at eddy center, which at cyclonic eddy has a lower temperature than the other months. In the cyclonic eddy at $109 \mathrm{~m}$ the temperature was about $11.9^{\circ} \mathrm{C}$ and in anticyclonic eddy the temperature was about $13.2^{\circ} \mathrm{C}$. Its indicated in September the

\section{Volume 5 Issue 3, March 2016}




\section{International Journal of Science and Research (IJSR) \\ ISSN (Online): 2319-7064 \\ Index Copernicus Value (2013): 6.14 | Impact Factor (2014): 5.611}

upwelling generated by the cyclonic eddy has a maximum phase. And this upwelling can be seen up to $222 \mathrm{~m}$, which the temperature at cyclonic eddy in $222 \mathrm{~m}$ was about $14.14^{\circ} \mathrm{C}$ while at anticyclonic was about $16.61^{\circ} \mathrm{C}$. Furthermore, strong intensity during September maybe caused by the intense of upwelling phenomenon occur in Southern Java Water during
Southeast Monsoon, also maybe caused by the ENSO. During El Nino events, sea surface temperature showed lower $\left(24-27^{\circ} \mathrm{C}\right)$ occured in the coastal to offshore regions of the Eastern Indian Ocean off Java, and warmer waters $\left(29^{\circ} \mathrm{C}\right)$ appeared in the eastern part of the Eastern Indian Ocean off Java [14].
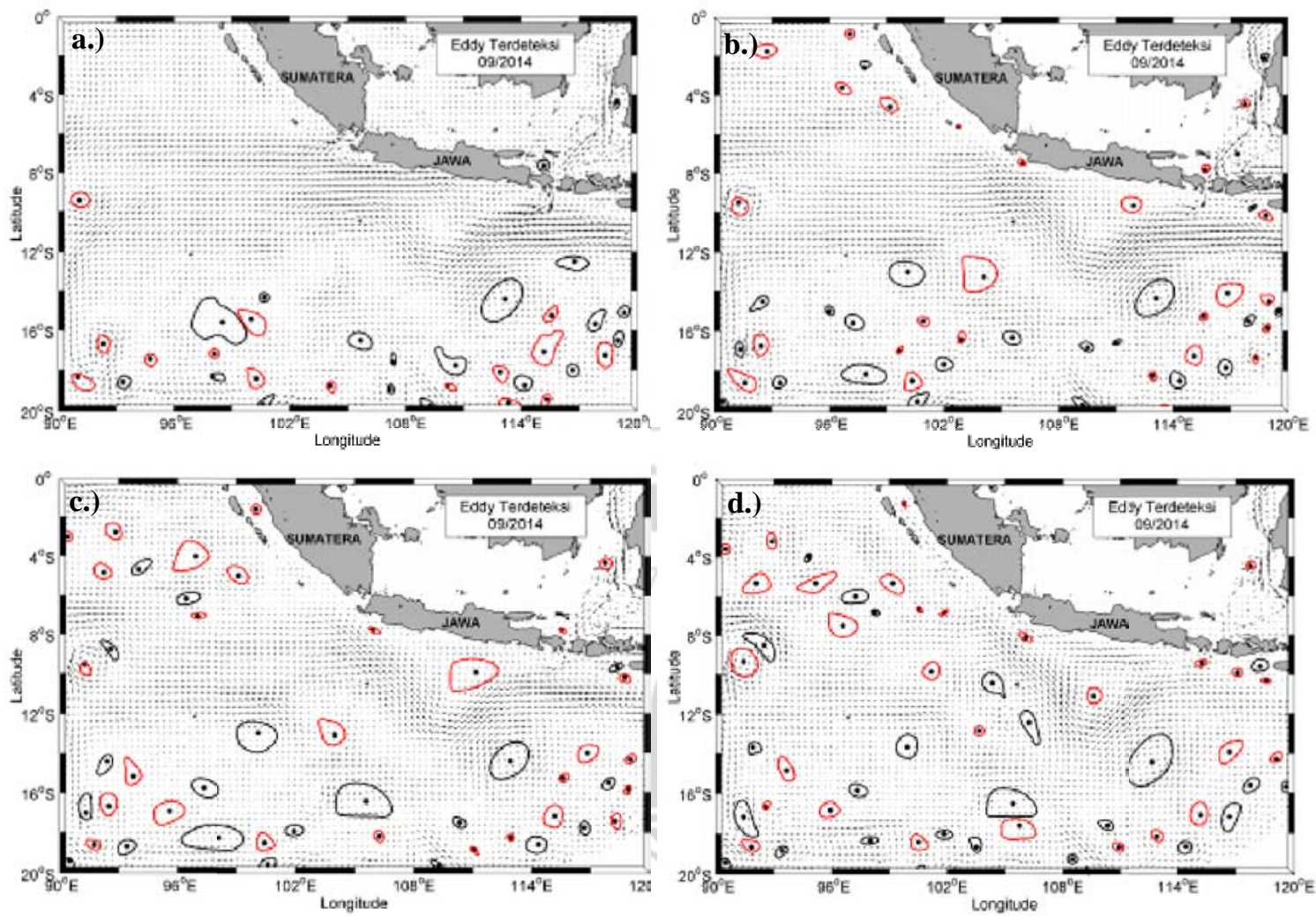

Figure 1: Eddy visualisation in September 2014 at four vertical levels a.) $5 \mathrm{~m}$, b.) $109 \mathrm{~m}$, c.) $155 \mathrm{~m}, \mathrm{~d}$.) $222 \mathrm{~m}$
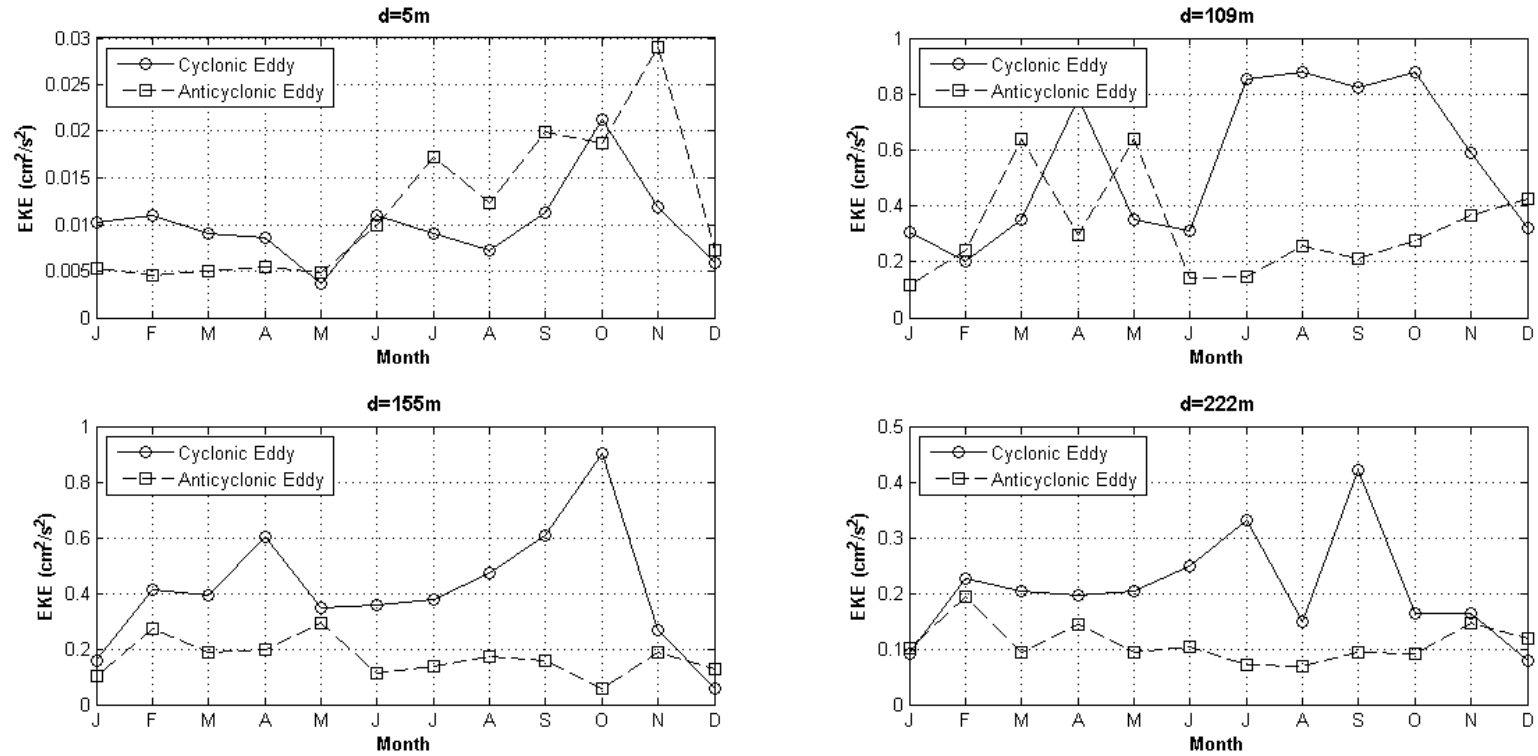

Figure 2: Mean EKE at four vertical levels during 2014

\subsection{Eddy Kinetic Energy}

EKE inside the eddy center mostly decrease within increasing of the depth. From $109 \mathrm{~m}$ to $222 \mathrm{~m}$ the EKE tend to decrease and at $155 \mathrm{~m}$ and $222 \mathrm{~m}$ the EKE has a constant value. From the Figure 2 showed that at $109 \mathrm{~m}$ has a higher EKE value.
EKE values showed a seasonal cycle with a maximum during Southeast Monsoon (July - September) and minimum during Transition System and Northwest Monsoon (December April). The increasing of EKE during Southeast Monsoon maybe caused by the instability of current system between SEC and ITF. ITF flow has a maximum intensity during 


\section{International Journal of Science and Research (IJSR) \\ ISSN (Online): 2319-7064}

Index Copernicus Value (2013): 6.14 | Impact Factor (2014): 5.611

Southeast Monsoon compared to the Northwest Monsoon [15].

The modulation of EKE is mediated by baroclinic instability associated with seasonal current system and the underlying westward-flowing SEC system and that makes EKE has a maximum value during Southeast Monsoon [16]. From all of depth mostly at cyclonic eddy has a higher EKE (0.01 - 0.55 $\left.\mathrm{cm}^{2} / \mathrm{s}^{2}\right)$ then at anticyclonic eddy $\left(0.01-0.31 \mathrm{~cm}^{2} / \mathrm{s}^{2}\right)$. In August the EKE between cyclonic and anticyclonic eddy has a significant difference. In cyclonic eddy at $109 \mathrm{~m}$ with a mean EKE of $0.880 \mathrm{~cm}^{2} / \mathrm{s}^{2}$ while in anticyclonic 0.257 $\mathrm{cm}^{2} / \mathrm{s}^{2}$. Its showed that cyclonic eddy has higher energy in transporting water system.

In June and December the EKE value between cyclonic and anticyclonic has a minimum value. In June mean EKE at cyclonic eddy was about $0.233 \mathrm{~cm}^{2} / \mathrm{s}^{2}$, while at anticyclonic eddy was about $0.091 \mathrm{~cm}^{2} / \mathrm{s}^{2}$. In December mean EKE at cyclonic eddy was about $0.116 \mathrm{~cm}^{2} / \mathrm{s}^{2}$, while at anticyclonic eddy was about $0.171 \mathrm{~cm}^{2} / \mathrm{s}^{2}$. Decreasing of EKE in eddy center during June and December maybe cause by the peak of the monsoon transition period occured in June and December and has the transition system of current at Southern Java Indian Ocean. Because of the transition system that occured in Southern Java Indian Ocean during this month caused weak value of EKE at eddy center.

\section{Conclusion}

The formation of eddy in Southern Java Indian Ocean are associated with the SEC, SJC, and ITF pattern. Total maximum of cyclonic eddy happened in January-March and July-September, while the anticyclonic eddy in April-June and July-September. Its indicated that cyclonic eddy is mostly formed by the baroclinic instability associated with the surface-intensified ITF and SJC system. Anticyclonic eddy is mostly formed by the baroclinic instability associated with the SEC system, beside that there are several factor that caused on anticyclonic form which is kelvin and rosby waves, wind trends, and the topography.

Characteristic of temperature at eddy center has a different value between cyclonic and anticyclonic, which at cyclonic eddy has a lower value than anticyclonic eddy. The temperature in eddy center mostly started changing at a depth of $109 \mathrm{~m}$ and fading at $222 \mathrm{~m}$. Characteristic of EKE at eddy center showed seasonal cycle with maximum in Southeast Monsoon and minimum in Transition and Northwest Monsoon. EKE at cyclonic eddy has a higher value $(0.01-$ $\left.0.55 \mathrm{~cm}^{2} / \mathrm{s}^{2}\right)$ then at anticyclonic $\left(0.01-0.31 \mathrm{~cm}^{2} / \mathrm{s}^{2}\right)$.

\section{Akcnowledgment}

The author would like to thank Research and Development of Marine Fisheries (Agency for Marine \& Fisheries R \& D) for provided the data and the facilities during the research process; Faculty of Fisheries and Marine Sciences, University of Padjadjaran for the facilities that have been provided; INDESO KP Project Research Agency which has been providing the dataset; and Komitmen Research Group who has helped in the discussion of data processing. Processing and analyzing the data mostly conducted in Laboratory of Marine and Coastal Data Development. Published fee in IJSR is funded by DIPA APBN P3SDLP KKP TA. 2016 for the Climate Change Policy Research Project.

\section{References}

[1] H. Martono, R. Komarudin, Syarief, S. Priyanto, D. Nugraha, "Studi Variabilitas Lapisan Atas Perairan Samudera Hindia Berbasis Model Laut," In Proceedings of the Seminar Nasional Aplikasi Sains dan Teknologi, 2008a.

[2] A.R. Robinson, Eddies in Marine Science, SpringerVerlag Berlin Heidelberg New York, 1983.

[3] P. Klein, G. Lapeyre, "The Oceanic Vertical Pum Induced by Mesoscale and Submesoscale Turbulance," Annual Review of Marine Science, 2015.

[4] A. Sell, Eddy - An Introduction: Impact on Marine Food Chains, University of Hamburg, Jerman, 2002.

[5] P. B. Rhines, Mesoscale Eddies, University of Washington, Seattle, USA, 2011.

[6] R. Mugo, S. Saitoh, A. Nihira, T. Kuroyama, "Habitat Characteristic of Skipjack Tuna (Katsuwonus pelamis) in the Western North Pacific: a Remote Sensing Perspective," Journal of Fish. Oceanography, 19 (5), pp. 382-396, 2010.

[7] C. Dong, X. Lin, Y. Liu, F. Nencioli, Y. Chao, Y. Guan, D. Chen, T. Dickey, J.C. McWilliams, "Threedimensional Oceanic Eddy Analysis in The Southern California Bight from a Numerical Product," Journal of Geophysical Research: Ocean, 117 (1), pp. 1-17, 2012.

[8] F. Nencioli, C. Dong, T. Dickey, L. Washburn, J.C. McWilliams, "A Vector Geometry-based Eddy Detection Algorithm and Its Application to a Highresolution Numerical Product and High-frequency Radar Surface Velocities in The Southern California Bight," Journal of Atmospheric and Oceanic Technology 27 (3), pp. 564-579, 2010.

[9] S.P. Kumar, M.T. Babu, D.P. Rao, "Energy and Generating Mechanism of a Subsurface Cold Core Eddy in The Bay of Bengal," Indian Journal of Marine Science, (21), pp. 140-142, 1992.

[10] N. Maximenko, J. Hafner, P. Niiler, "Pathways of Marine Debris Derived from Trajectories of Lagrangian Drifters," Mar. Pollut Bull, 65, pp. 51-62, 2012.

[11] S. Zheng, Y. Du. J. Li, X. Cheng, "Eddy Characteristics in The South Indian Ocean as Inferred from Surface Drifters," Journal Ocean Science, 11 (3), pp. 361-371, 2015.

[12] J. Sprintall, J.T. Potemra, S.L. Hautala, N.A. Bray, W.W. Pandoe, "Temperature and Salinity Variability in The Exit Passages of The Indonesian Throughflow," Journal Deep-Sea Research II (50), pp. 2183-2204, 2003.

[13] M. Piedeleu, P. Sangra, A. Sanchez-Vidal, J. Fabres, C. Gordo, A. Calafat, "An Observational Study of Oceanic Eddy Generation Mechanism by Tall Deep-Water Islands (Gran Canaria),” Journal Geophysical Research Letters (36), pp. 1-5, 2009. 
[14] M.L. Syamsuddin, S. Saitoh, T. Hirawake, S. Bachri, A.B. Harto, "Effects of El Niño - Southern Oscillation Events on Catches of Bigeye Tuna (Thunnus obesus) in The Eastern Indian Ocean off Java," Fishery Bulletin 111 (2), pp. 175-188, 2013.

[15] M. Safitri, S.Y. Cahyini, M.R. Putri, "Variasi ARLINDO dan Parameter Oseanografi di Laut Timor sebagai Indikasi Kejadian ENSO," Jurnal Ilmu dan Teknologi Kelautan Tropis 4 (2), pp. 369-377, 2012.

[16] F. Jia, L. Wu, B. Qiu, "Seasonal Modulation of Energy Kinetic Eddy and Its Formation Mechanism in the Southeast Indian Ocean," Journal of Physical Oceanography 41 (4), pp. 657-665, 2011.

\section{Author Profile}

Armyanda Tussadiah received the B.S. degrees in Marine Science from University of Padjadjaran in 2016. During study in Marine Science she was appointed become an assitant lecture for several subjects. In February 2016 she accepted as a Operator Data of Fisheries Oceanography at Marine and Coastal Data Laboratory, Research \& Development Center for Marine \& Coastal Resources, Ministry of Marine Affairs \& Fisheries Republic of Indonesia.

Mega L. Syamsuddin holds a Ph.D in Satellite Oceanography from Hokkaido University, Japan. She joined Padjadjaran University as a lecturer in January 2008. Her research focused on the application of remote sensing on fishing ground identification due to ocean climate variability. She has published her work in Fishery Bulletin, Energy Procedia and International Journal of Remote Sensing.

Widodo S. Pranowo holds a Ph.D in Mathematics Techno from the University of Bremen and the Alfred Wegener Institute for Polar and Marine Research, Germany in 2010. Since 2011 he became a scientist in Research \& Development Center for Marine \& Coastal Resources of the Ministry of Maritime Affairs and Fisheries and in early 2014 also active as a lecturer at the Department of HydroOceanographic Naval Technology High School. Since 2014 he was appointed as Coordinator for End-Users of Satellite Application for Oil Spill Monitoring in the program "Indonesia Infrastructure Development for Space Oceanography" (INDESO).

Noir P. Purba received the B.S. in Marine Science from University State of Riau and M.S. degrees in Earth Science from Bandung Institute of Technology from 2005-2008. During 2010-2015, He work in Padjadjaran University as a lecturer and researcher in Oceanography. And, with the same years become President of KOMITMEN Research Group.

Indah Riyantini received the B.S in Marine Science from Dipenogoro University and M.S degree in Biological Resource Management from Bandung Institute of Technology. She joined Padjadjaran University as a lecturer in 1987. Her research focused on Marine Biology. During 2008 - 2014 she did several research about marine ecosystem and marine biology. 